\title{
Changing World: Music and Youth
}

"Three things will last forever; faith, hope and love. But the greatest of these is love"

(1 Corinthians 13:13, New Living Translation)

My physique is that of solid build, like my maunga that stands tall and strong.

I am a full-bodied woman with round curves which outline the river bends of my awa.

I have big brown eyes that have seen the struggles and triumphs, of my whanau, past and present.

The two feet I stand on represent my Samoan and Māori wakas. Both keep me moving for my aiga, iwi into the future.

\section{Lights, camera, action!}

It is all on from here, there is no turning back now. It is the dreaded fear of forgetting lyrics you know inside out, or messing up a simple dance routine where you have been over the steps a thousand times just before you step out on to the big stage.

These are pressures all singers and performers from professional, aspiring or experienced know of, but understand it is the learning from these experiences we become stronger and better equipped in our craft.

Much is to say about life with its ever-teaching experiences and growth in learning who we are and what we have to give. In this article, I will endeavor to take you on a journey 
introducing key people who have been positive driving forces in helping me navigate my way through life. You will begin to see why music and youth go hand in hand for me as you become familiar with my family, background and journey.

Blessed I am with having the opportunity to work closely with youth of all ages in my community, as a teacher of life skills and valued based programs ages from the new entrance to the intermediate level. I am also currently working as a facilitator and Programme Coordinator for a Careers and Peer mentoring based programme, both delivered to College level students. My positions place me in the necessary environment to be of positive influence with building positive relationships with rangatahi.

Apart from my love for teaching I am also a music recording artist. My love for teaching about values and principles and passion for music go hand in hand. The passion I have for both music and teaching youth has been inspired by influential teachers I have in my own family.

Both professions allow me to speak life, allow me to share experiences, shed light, bring forth issues I feel need to be heard and brought out into the open. Using music as a medium to teach and communicate through, enables me to reach youth in a more special, unique and creative way.

The reason I have decided to embark on this journey of Music and youth as I feel there to be a great need for good role models in music.

Role models who use their gifts of song and music to nurture, uplift and empower rangatahi. It is with hopes my talents and gifts in Music and teaching will help the future growth of rangatahi.

\section{Grandmother, Fitu Leuluai}

She stands a little under average height with long, thick black hair with skin so youthful looking many people have asked what her secret is. She takes pride in the way she presents herself 
wrapping her long black locks up into a bun making sure no strand of hair is out of place. She is always dressed in a beautiful traditional Samoa puletasi before leaving the house. A strong woman of faith who loves her God, our family prayer warrior and strong pillar who keeps order and peace.

The lady I have described is my beautiful grandmother. A little, soft-spoken lady with the singing power of a 10-piece choir with an extensive vocal range. My first teacher of Samoa hymn music and song.

My grandmother was a real leader when it came to sing whether it was for church, at home or for family events. You could tell she was a leader because everyone would look to her and wait for her first note before joining in. I wanted to sing with my grandmother but for the most part, songs were sung in the Samoan language. My Samoa language is not strong, so I would watch the way her lips moved around words and copy exactly what she did, this made her smile.

I remember sitting in church and from time to time you would have ladies in the congregation try to compete with her high-end soprano but would falter when hitting the notes like she did. My grandmother knew she was good, I just did not understand why she would have me and my little sister sitting right up to the front of church every sabbath morning. It was as though the closer we were to the front of the church, the closer we were for the heavens to hear us sing.

So bold and ready she stood, as she waits to deliver her song with conviction. Even though I did not understand the words of the songs I felt every word because she gave each word life and meaning. I wanted to sing with the same heart and purpose and I too wanted to be a leader just like my grandmother.

\section{Mother, Johanna Tepania}

A creative being who loves her colors and shapes. She lets her imagination lead, as she creates without rule or restriction because she believes creativity is what comes from you, it is 
what you make it. In my eyes, everything my mother touches turns to gold leaving things better than it was when she first found it.

I admire how very careful and particular she can be when she creates. I have watched her closely as her hands follow her eyes in perfect unison as she takes a brush to paint the finest of details or a scissors to cut the most intricate of patterns. She takes her time and ensures every detail is exactly right and how she has pictured in her mind.

In school I was taught to color within the lines, taught there were certain rules you must follow if you were to make good music. This never felt right to me as I found much joy creating pictures of my own outside the lines. I loved using structures I felt comfortable with even if that meant I was going to rearrange a common song structure to better suit my music. I agree with (John Baer, n.d.), "Creativity refers to anything someone does in a way that is original to the creator and that is appropriate to the purpose or goal of the creator" My mother taught me, "creativity is your own" (Tepania. J, personal communication, 2000) and no one should tell me how and what it should look like for me.

You will always remember your favorite teacher for many reasons. Perhaps you were acknowledged by the warmest of smiles, or greeted with an energy packed "hello" every morning. You may remember the teacher because they made learning fun for you and eliminated all fears of being incapable, incompetent and inadequate. My mother was a favorite teacher for many of my friends as they would question my mother's where about when she was not with me. I believe a lot has do with her light source, enthusiasm and energy which naturally radiates from her.

My mother's creativity and resourcefulness light and energy flows through me and is my greatest of gifts when it comes together with my teaching and music. 


\section{Father, Joshua Sasa - Potoi}

Across the road from the flats where we lived, a little grass area where my father would point out to me and say, when both my feet are able to touch the pedals of the bike I promise to teach you how to ride your first bike.

As time passed I had been constantly measuring myself against the bike, as soon as my feet touched the pedals I ran straight to my father and reminded him of his promise.

The day had come, that day was finally here and there we were, my father holding my hand, me with my bright pink helmet pushing a bike that was far too big but It did not worry me, looking up at my father I knew he would not let me fall.

We walked up onto the grass area were my father sat me on the oversized bike, I remember at this point the palms of my hands became very sweaty, knees were a little shaky and my heart was racing a thousand miles per hour. He kneeled beside me not a word came from him as he waited patiently until I was ready to move. A few minutes passed, he looked up at me and I nodded my head indicating I was ready.

He would hold the back of the bike and run alongside me until I had steady control and would then let me pedal on my own. There I was, riding my first bike, although there were a few run inns with powerlines before I really got the balance, father always ran to my aid and dusted me off encouraging me to try again.

Because of my father's love for me I overcame many obstacles. The hard-concrete powerlines I rode my bike into that day represents the many physical and emotional struggles he has seen me through.

My father has taught me resilience, never giving up on something or someone however hard things may seem. He has shown me the power of patience, where there are times words are not needed and being a presence for someone is enough.

My father also role modeled what a good father figure should look like and what it is I look for in my future husband and father of my children. 
A man who fathers a child which is not their own deserves to be praised. I cannot begin to describe with words, my heart of gratitude and love for my God in bringing this man I call father and his family into my life. My beliefs are if it were not God's plan life may have turned out a little differently for me today. I will forever be thankful.

\section{Hands on learning through hard work}

Reflecting on childhood upbringing learning came by way of watching, doing, feeling and experiencing. We did not talk about how to assemble something or sit down and have a group discussion on its functions. If there was something which needed to be done, it was first shown and then an expectation to know by demonstrating.

There were sure differences in learning styles between both my Samoan and Māori families, though very few. In my Samoan fale questions were neither encouraged or asked, my father goes on to say, "practical way of learning, don't ask questions just do it." (Sasa-Potoi, J. personal communication, April 28, 2018). It was very much having to get it right the first time. Instructions on how to do things were few so I really had to pay attention. However, my Māori whānau were very relaxed and would talk me through things or let me experience for myself how certain things worked.

Tanaka (2016) wrote “...learning is a natural instinct" (p.12). The asking of questions would be the opposite of what "instinct" means to me. So, my understanding now as to why we were not encouraged to ask questions, may have been that we were instinctively meant to know what to do. Our ancestors were hardworking and physical beings; it is in our blood.

In a recent conversation with my Samoan aunt Josephine she explained,

"Grandma taught us a lot through showing us what to do, telling us about her upbringing and comparing Samoa to 
NZ... when it came to discipline as a way of teaching and learning it was very harsh if we didn't listen or do what we were shown properly. It is not encouraged to ask questions, it was almost disrespectful. We watched how things were done and had do the same with little mistake" (Samuelu. J, personal communication, April 22, 2018).

Whereas, my aunt Melissa from my Māori side goes on to say,

"I was taught how to be independent in gathering for my whanau. I collected greens, picked puha, watercress, poroporo, pohatu. I was shown how to gather kaimoana and eeling and to always throwback the first you find or catch. We learnt to be respectful to land by putting rocks back the way you found them. Never turn your back on the sea. We were spoken to a lot so we learnt by listening and watching carefully" (Martin. M, personal communication, April 28, 2018)

To quote Tanaka (2016) "Nature is the first teacher." Listening to the stories of my family's upbringing and how learning was of doing and experiencing, the classroom in which they were being taught in was nature itself by land and sea. Real life situations gave my family the basic setting for most indigenous learning and teaching (Tananka, 2016).

\section{Learning through songs and melodies}

The first Samoan song taught to me by my grandmother as a child is called, My God loves me. This song teaches about what God has done and speaks of his love. Most of the Samoan songs I know today are Christian, Sabbath school songs taught by my grandmother. The Maori songs I know are those learnt through school. Songs of karakia and songs to do with learning the different parts of the body. When I begin to think about just how 
much of the reo I know, it is through waiata I know the language.

For Ebong (2004), music exists in the human experience from birth to death. The first beat we know and hear is the beat of our mother's heart when we are in the womb. It is also the last beat we feel clinging close to our chest when we take our last breath. Much like the first sound of our mothers beating heart which remains in our inner most being, so too are the songs which have been handed down and taught to us as children.

Aunty Josephine had mentioned,

"The Samoan indigenous methods of teaching and learning is usually through story telling or oratory - passing of knowledge and teaching through talanoa (talking, dialogue, discussion, using metaphors and stories). Grandma has a beautiful voice and would teach the Samoan alphabet, the books of the bible and memory verses through song. She has a song for everything and uses song to teach the family of God's love" (Samuelu. J, personal communication, April 22, 2018).

My mother adds,

"There was something about your ear for pitch and melody as you would listen and imitate certain sounds, you would pick up songs very quickly. More effort should have been made to cater to your learning style. Maybe we could have done more song, melody learning with some of the subjects that were a little harder for you. We may have seen a difference in learning for you, your experience in the mainstream may have been better" (Tepania, J. personal communication, May 01, 2018). 


\section{Learning in a family atmosphere}

Learning at home in comparison to learning in the school space were two very different things for me. Within the school space I did not feel valued; just another name on a list of many and I felt neglected. I am a visual and practical learner so it is necessary for my learning to hold something, touch or feel in different ways for me to comprehend and understand as oppose to just being spoken to.

Durie (2011) said "Poor teachers fail to convey enthusiasm for their subject, or their students, place undue emphasis on conformity" (p.129). There was something about the way I was taught at school which did not help me or cater to the different learning styles and needs of many students. It felt like everyone was taught one specific way and I was having to force myself to understand in a way which did not come naturally. Within the space of whānau, aiga atmosphere of learning, everyone learns with each other and from one another. Everyone has a role, a responsibility to the learning and to each other. Working together is key to learning and success. Every individual is acknowledged and no one is left behind.

Durie (2011) also explains whanaungatanga as the building of relationships as a vital whanau function that contributes to human potential (p.179). I feel that if my teachers had taken the time to build positive relationships with me, or took a genuine interest in my learning instead of thinking of me as time consuming learner, my school experience may have been a little different.

I needed to ask my mother of her learning experience growing up and she goes on to say,

"Learning at school was hard for me. I did not understand a whole lot at school so my learning came through family activities, chores and life experiences with friends. I see a lot of me in you. We are creatives and learning needs to come from different angles, colours and movement to help. Firstly, a safe space of ahurutanga needs to be created for us to feel comfortable and 
confident. For me my safe space was with family and friends so that is where most my learning came from." (Tepania, J. personal communication, April 26, 2018).

My aunty Melissa added,

"Yes, I learnt through working on the land. We had a farm, so mustering on horseback, breaking in horses was a must, a lot of hard labor.... Working in the shearing shed, gardening, haymaking, hunting. On the marae we had to do our share of mahi, i.e. food prep, picking kai, catching kai going to gather kaimoana, dishes! A lot of this because you were with cousins and aunties and uncles made it more fun than work.... Loved marae life and learning with whānau" (Martin. M, personal communication, April 28, 2018).

Aunty Josephine replies,

"It was important to grandma for us to learn as a family the Samoan language, understanding traditions and making connection to culture. My siblings and I would read the Samoan Bible every night so that we learnt how to speak Samoan. Every time we stood at the front of church we had to speak Samoan. I learnt fa'asamoa at family meetings and gatherings. I would listen to elders speak and then practicing speaking in Samoa. I learnt most of my Samoan in the home with my aiga" (Samuelu. $\mathrm{J}$, personal communication, April 22, 2018).

\section{Learn through Faith}

Learning by way of faith has played a major part in my life and still does. Growing up in a Seventh Day Adventist home where most weekends were spent at my grandmother's and attending church; this was not always easy. There were rules when it came to our Sabbath day of worship; school sports were out of the question; we were not allowed to participate in sports of any 
kind. Saturday was a holy day set apart for things of worship alone. No shopping or going to shops; no watching TV, loud music or playing. As a child it was a little hard as I was heavily into sports at the time and not being able to attend had me in tears at times. I missed out on a lot but had gained so much more at the same time learning from my grandmother and watching her faith in God.

Being surrounded by the Gospel where prayer was very much needed in our lives; reading scripture was encouraged and church was compulsory: this was my childhood. This is what every weekend looked like for me and I would not exchange the knowledge that gained about God for all the netball games or friend gatherings in the world.

My aunty goes on to say,

"Grandma was raised in the fa'asamoa way but heavily influenced by Christianity and the way she brought us up here in NZ was the way she learnt in Samoa except, we did not practice the fa'asamoa when growing up because Seventh Day Adventists do not practice a lot of the fa'asamoa. We were raised and taught through Christian values and beliefs" (Samuelu. J, personal communication, April 22, 2018).

My aunty Melissa shares,

"A lot of cultural learning was done on the marae but also our spiritual learning. We did not believe in a God. Our family are spiritual and we have our own beliefs that pertain to land and sea as oppose to Christianity" (Tepania. J, personal communication, April 30, 2018).

According to Tavana, Hite and Randall (1997), Samoan cultural values are central to the individual and collective identity of the Samoan people and guide their way of life. For 
my grandmother, however, her faith in Christ guided her life and anything to do with culture came second.

I had asked my father about faith and his Christian upbringing,

"Grandma was very strong in the Seventh Day Adventist faith where Christianity was first and cultural agendas were last. The Bible was accepted as the only source of belief and way of living. (Sasa-Potoi. J, personal communication, April 28, 2018).

I developed a model called the Leo model. This model is based on my voice. To access this mdoel, one must scan the below QR code and listen.

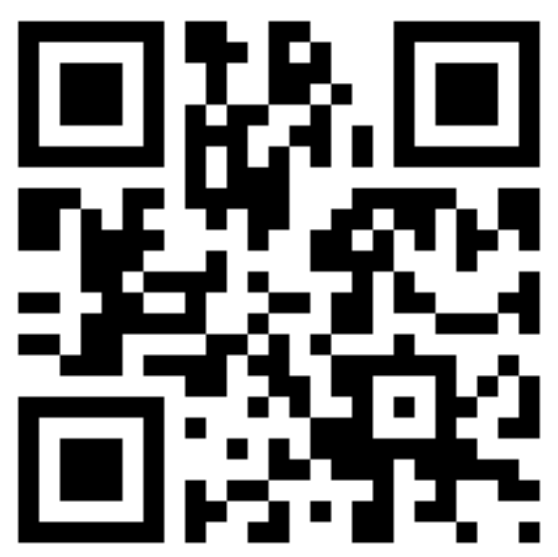

The word Leo is the Samoan word for voice. My model (scan the QR code) uses the sound of my vocals to illustrate its values and principles in relation to one another. I am using an old Sabbath school song my grandmother taught me which is also the first Samoan song I learnt as a child called "My God Loves Me" 
It is through songs I learnt the Samoan language, through songs I learnt of God's love for me. Singing is one of my family's strongest means of communication with each other. It felt natural to convey the Leo model through using the sound of voice. "In indigenous societies, oral traditions form the "distinct ways of knowing and the means by which knowledge is reproduced, preserved and conveyed from generation to generation" (McNab.D, 2013)

I believe the voice is the most important instrument we have and own. After much thought and numerous attempts with drawing picture's and symbols to show my model through, I had come to realize, the Leo model is not meant to be drawn, it is meant to be sung. To see this another way, using vocals I can demonstrate my model in a more creative way which may be more appealing to the imaginative, creative, artistic and musically inclined.

\section{The Leo model has five dimensions:}

God - O LE ATUA (could be the beliefs of a person)

You - O A'U (includes everything around wellbeing, spiritual, physical, mental and emotional of a person)

Family - AIGA (community, wider community)

Love - ALOFA (love for yourself, love for what you do, love for others)

Respect - FA'AALOALO (respect for other thoughts, feelings, space and environment)

Growing up a Samoan, Māori woman I have had the best of both worlds. My parents knew the importance in making sure me and my little sister spent time with both sides of the family, learning about the different cultures. Both families have similar values and principles within the home in which they teach and live by. It is through these teachings and my lived experiences I have developed my model through.

My grandmother taught me to keep God at the centre of my life and everything will fall into place. She would say, even 
though this world and the people in it may change, He will remain the same. "Jesus Christ is the same yesterday, today and forever." (Hebrews 13:8 NIV)

\section{The Leo features explained:}

God - O LE ATUA (beliefs of a person)

To begin my sound model, you will hear just one voice. This voice stays the same throughout the piece it does not change. It is the underlying melody in which the other voices get their note from to harmonize and gives direction in knowing where to go.

For me this voice represents God but for others, it may be their beliefs, values or principles that center their lives. Every other feature surrounding this source has been given life and meaning because the center gives you purpose.

You - O A'U (includes everything around wellbeing, spiritual, physical, mental and emotional of a person) and Family - AIGA (community, wider community)

The next sound you will hear another voice to support and accompany. The extra voice you are hearing is sung in the octave of the first voice. So, it is the same note just sung an eighth higher. The voice and notes of the Leo model all derive or stem from your center. This part of the Leo model illustrates, you - O a'u and family - aiga and the support needs to be the same in correspondence to each other for wellbeing of the physical, mental spiritual and emotional self.

Love - ALOFA (love for yourself, love for what you do, love for others) and Respect - FA'AALOALO (respect for other thoughts, feelings, space and environment)

The next lot of voices illustrate love and respect weaving between the features of the Leo model. 
The feature of Respect and Love bind the model together weaving in and around all the other parts. For me Love and Respect can look like many different things and so here, I wanted to use the many different colors of my voice and create a movement action to illustrate weaving

"Aroha is truly a divine love because it knows no bounds, and is infinite." (Pere, 1997, p.6)

The Leo model will then leave you with the voice of Atua, or one's beliefs to end. This is to illustrate my belief in God as being the beginning and the end of all things.

\section{Creating the Leo model:}

Before creating the Leo model, I began to look at other indigenous models of understanding. I found most have common features and themes and most were based on health and the wellbeing of a person.

Looking at my family and how I was brought up, we are very simple people. We live by simple rules, lead simple lives so when creating my model, I wanted it to be very easy to understand.

Models like Te Wheke, Fonofale and Tivaevae all have something to say about the relationship of each feature working together,

"The dimensions are interwoven and this represents the close relationship of the tentacles" (Ministry of health, 2017).

"The concepts of Tivaevae are intertwined with each other rather than single separated..." (Te Ava, Airini and RubieDavies, 2014).

"...all aspects depicted in the Model have an interactive relationship with each other." (Fuimaono, 2001).

Collaboration, reciprocity and interrelating values and principles are articulated here and I wanted my model to make sure it was showing the same relationship between each with helping understand one works well with the other but together is much stronger, colourful. 
The Leo model is very innovate using a QR code as a link to the sound scape. The model is also creative in a way which uses sound harmonies and melodies to illustrate the functionality of my model very different from a sketched, drawn model.

\section{Learning through speaking the language}

The Māori language was spoken very little in my home although with the very few words we did know, we would use. As McRae (2017) wrote It was essential in an oral tradition to keep repeating what was important to make sure it survived in the memory and passed on. My mother made sure we learnt some Māori words and did her best to share what she knew of her Māori culture. The Samoan language however was spoken daily and it was preferred in grandma's home. Learning the Samoan language was easy as it was spoken regularly.

Aunty Melissa said,

"Te Reo was not spoken often in the home my parents came from the generation that got caned for speaking it" (Martin. M, personal communication, April 28, 2018).

Aunty Josephine said,

"We were encouraged to speak Samoan in the home especially. It was preferred as grandma did not speak great English. To this day grandma prefers we speak to her in Samoan." (Samuelu. J, personal communication, April 22, 2018).

Similarly, my father stated that

"The Samoan language I learnt from attending a Samoan church, reading the Bible and singing hymns in the Samoan language. We practiced speaking a lot whilst growing up, 
especially when we were in front of our elders and church family" (Sasa-Potoi, J. personal communication, April 28).

\section{Smile, take a bow, curtain close!}

As the curtain slowly draws you begin to reflect on your performance asking yourself, did you give the performance of your life leaving everything out on the floor? Did you reach out and make those much-needed connections with people in your crowd? If you had the chance again would you do differently?

These questions I ask myself after every music performance and after every teaching lesson in the classroom with my students. The teachers which you are now familiar with in my family have and continued to give me the best of their knowledge, love and time in helping me find who I am and what I have to offer. It is in my heart to give the same attention, making the biggest impact with my music and in the lives of the youth. 


\section{References}

Durie, M. (2011). Navigating Maori Futures. Wellington, Aotearoa: Huia Publishers

Ebong, B, (2004). The use of indigenous techniques of communication in language learning: The case of Cameroon. Gottingen: Cuvillier Verlag.

Fuimaono Karl Pulotu - Endemann. (2001). Fonofale model of health. Retrieved from: http://www.hauora.co.nz/resources/Fonofalemodelexplan ation.pdf

McNab, D. (2013). Indigenous Voices and Spirit Memory. Winnipeg, Manitoba: Aboriginal Issues Press.

McRae, J. (2017). Maori oral tradition: He korero no te Ao Tawhito. Auckland, New Zealand: Auckland University Press.

Ministy of Health. (2017, May 18). Maori health models - Te Wheke. Retrieved from: https://www.health.govt.nz/ourwork/populations/maori-health/maori-healthmodels/maori-health-models-te-wheke.

Tanaka, TD. MC. (2016). Learning and teaching together: Wearing indigenous ways of knowing into education. Canada: USB Press.

Tavana, G.V., Hite, S.J., Randall, E.V. (1997). Cultural Values and Education In Western Samoa: Tension Between Colonial Roots and Influences and Contemporary Indigenous Needs. International Journal of Educational Reform, 6(1), 11-18.

Te Ava, A., Airini., \& C Rubie-Davies. (2014). Akaraka akaouanga I te kite pakari o te tuki airani: Culturally responsive pedagogy. Pacific - Asian Education, 2(2), 117128.

Te Whaiti, P., McCarthy, M.B \& Durie, A. (1997). Mai i rangiatea: Maori wellbeing \& development. Auckland, New Zealand: Bridget Williams Books. 